\title{
PERAN PARTAI POLITIK DALAM DEMOKRASI PERWAKILAN
}

\author{
M. Alpi Syahrin, \\ Universitas Islam Negeri Sultan Syarif kasim Riau, Email: msyahrin@uin- \\ suska.ac.id \\ Imelda Sapitri, \\ STIT Al Kifayah Riau, Email : imelda932016@gmail.com
}

\begin{abstract}
The party plays a very strategic liaison role between the governmental processes and the citizens. In a democracy, the presence of political parties is a necessity in order to play a representation function when political parties enter the electoral arena. In elections, political parties can be said to be the sole actor filling positions in state institutions. Political parties can propose the dismissal of members of the House of Representatives. Therefore, it is natural that recall for Senayan politicians is considered a scourge, or a mine of democracy. The control mechanism also cannot override the people's sovereignty, and can even shackle members of the council who speak up for the aspirations they represent. Considering that great power tends to give birth to abuse of power, which results in members of the House of Representatives unable to express freely in voicing the aspirations of the people they are represented because they have to follow party policies and directions so that there is a relationship between representatives and those represented as participants. Every country has a representative system as well as Indonesia sees that there are three institutions that are in the legislative clump, namely the People's Consultative Assembly, the People's Representative Council, the Regional Representative Council with separate powers granted by the 1945 Constitution of the Republic of Indonesia so that the representative system adopted Indonesia is a system that is uniquely Indonesian because it was formed to embody the needs, interests and challenges of the Indonesian nation and state.
\end{abstract}

Keywords: Political Parties, Participants, Representatives

\section{Abstrak}

Partai memainkan peran penghubung yang sangat startegis antara proses-proses pemerintahan dengan warga negara. Dalam demokrasi kehadiran partai politik adalah suatu keniscayaan dalam rangka memainkan fungsi representasi manakala partai politik masuk ke arena pemilu. Dalam pemilu, partai politik boleh dikatakan sebagai aktor tunggal pengisian jabatan dalam lembaga-lembaga negara. Partai politik dapat mengusulkan pemberhentian anggota Dewan Perwakilan Rakyat Oleh 
karena itu, wajar apabila recall bagi kalangan politisi senayan dianggap sebagai momok, atau ranjau demokrasi. Mekanisme kontrol itu juga tidak boleh mengesampingkan kedaulatan rakyat, bahkan dapat membelenggu anggota dewan yang menyeruakan aspirasi yang diwakilinya. Mengingat kekuasaan yang besar cenderung melahirkan abuse of power sehingga mengakibatkan anggota Dewan Perwakilan Rakyat tidak dapat berekspresi secara bebas dalam menyuarakan aspirasi rakyat yang diwakili karena harus mengikuti kebijakan dan arahan partai sehingga yang terjadi hubungan antara wakil dan terwakili sebagai partisipan. Setiap negara memiliki sistem perwakilan begitu juga Indonesia melihat ada tiga lembaga yang berada dalam rumpun legislatif yaitu Majelis Permusyawaratan Rakyat, Dewan Perwakilan Rakyat, Dewan Perwakilan Daerah dengan kewenangan secara tersendiri yang diberikan oleh Undang-Undang Dasar Negara Republik Indonesia 1945 maka dapat sistem perwakilan yang dianut Indonesia merupakan sistem yang khas Indonesia karena dibentuk sebagai perwujudan kebutuhan, kepentingan serta tantangan bangsa dan negara Indonesia.

Kata Kunci: Partai Politik, Partisipan, Perwakilan

\section{Pendahuluan}

Pada zaman renaissance timbul teori yang mengajarkan bahwa dasar hukum itu adalah akal atau rasio manusia. Menurut aliran rasionalisme ini, bahwa raja dan penguasa negara lainnya memperoleh kekuasaannya itu bukanlah dari tuhan tetapi dari rakyatnya. Pada abad pertengahan diajarkan, bahwa kekuasaan raja itu berasal dari suatu perjanjian antara Raja dengan rakyatnya yang menaklukkan dirinya kepada raja dengan syarat-syarat yang disebutkan dalam perjanjian itu. Kemudian setelah itu dalam abad ke 18 Jen Jacques Rousseau memperkenalkan terorinya bahwa dasar terjadinya suatu negara adalah perjanjian masyarakat (contrat social) yang diadakan oleh dan antara anggota masyarakat untuk mendirikan suatu negara. Teori JJ Rousseau menjadi dasar paham kedaulatan rakyat mengajarkan bahwa negara bersandar atas kemauan rakyat, demikian pula halnya semua peraturan perundang-undangan adalah penjelmaan kemauan rakyat. ${ }^{1}$ Dalam Undang-Undang Dasar Negara Republik Indonesia 1945 menganut kedaulatan rakyat sebagaimana tertuang dalam Pasal 1 ayat (2) yang berbunyi "Kedaulatan adalah ditangan rakyat dan dilaksanakan berdasarkan UUD. Dalam paham kedaulatan rakyat, yang di daulat dari segi politik tentu saja bukanlah person rakyat itu sendiri, melainkan proses kehidupan kenegaraan secara keseluruhan. Hubungan kedaulatan bukan

${ }^{1}$ Titik Triwulan Tutik, Pengantar IImu Hukum, Prestasi Pustaka, Jakarta, 2006. 
lagi terjadi antara Raja dengan rakyatnya, tetapi antara rakyat dengan proses pengambilan keputusan dalam negara itu sebagai keseluruhan. ${ }^{2}$

Dalam kedaulatan rakyat dengan sistem perwakilan atau demokrasi biasa juga disebut sistem demokrasi perwakilan (representative democracy) atau demokrasi tidak langsung. Didalam praktik, yang menjalankan kedaulatan rakyat itu adalah wakil-wakil rakyat yang duduk di lembaga perwakilan rakyat yang disebut parlemen. Sistem pemerintahan yang demokratis dimana kebijaksanaan umum ditentukan atas dasar mayoritas oleh wakil-wakil yang diawasi secara efektif oleh rakyat dalam pemilihan-pemilihan berkala yang didasarkan atas prinsip persamaan politik, dan diselenggarakan dalam suasana terjaminnya kebijaksanaan politik. Demokrasi formal ditandai dengan pemilihan umum yang teratur, bebas dan adil, kompetitif. Terdapat kebebasan sipil dan politik yang cukup untuk menjamin kompetisi dalam pemilihan umum. ${ }^{3}$

Partai politik mempunyai posisi (status) dan peranan (role) yang sangat penting dalam setiap sistem demokrasi. Jimly Asshiddiqie mengatakan " partai politik merupakan pilar demokrasi, karena mereka memainkan peran yang penting dan strategis dalam menghubungkan pemerintah dengan warga negaranya. Dapat dikatakan bahwa partai politiklah yang mewujudkan demokrasi pada suatu kenyataan. ${ }^{4}$ Sehingga peran besar yang dimiliki oleh partai politik tersebut memiliki pengaruh secara langsung kepada wakil rakyat yang tidak lain adalah anggota partai politik.

\section{Metode Penelitian}

Penelitian ini adalah peneltian normatif. Penelitian hukum normatif sendiri adalah penelitian hukum yang dilakukan dengan cara meneliti bahan pustaka atau data sekunder. ${ }^{5}$ Sifat penelitian dalam penyusunan tesis ini adalah deskriptif-analitik, yakni suatu usaha untuk mengumpulkan dan menyusun suatu data, kemudian dianalisis dan ditafsirkan. ${ }^{6}$ Dengan artian

2 Jimly Asshiddiqie, Konstitusi \& Konstitusionalisme Indonesia, Sinar Grafika, Jakarta, 2011. HIm 122

3 Hartati, Menatap Masa Depan Dewan Perwakilan Daerah, CV Trisar Mitra Utama, Jambi, 2018. HIm 29

${ }^{4}$ Atas dasar itu Jimly Asshiddiqie lebih lanjut mengatakan bahwa partai politik sebagai pilar atau tiang demokrasi, sangat perlu dan penting diperkuat derajat kelembagaannya dalam setiap sistem politik yang demokratis. Derajat pelembagaan partai politik itu sangat menentukan kualitas demokratisasi kehidupan politik suatu negara. Sebab, keberadaan partai politik berkaitan erat dengan prinsip-prinsip kemerdekaan berpendapat, berorganisasi dan berkumpul. Lebih lanjut lihat Marojahan JS Panjaitan, Politik, Hak Asasi Manusia Dan Demokrasi Dalam Bingkai Negara Kesejahteraan Dan Kebahagiaan Menurut UUD 1945, Rineka Cipta, Bandung, 2018. HIm 12.

5 Salim HS dan Erlies Septiana Nurbani, Penerapan Teori Hukum Pada Penelitian Tesis dan Desertasi, PT Raja Grafindo, Jakarta 2013, HIm 12

${ }^{6}$ Winarno Surahcmad, Pengantar Penelitian IImiah, (Dasar, Metode, Teknik), Tarsito,Bandung, 1990. HIm. 139-140 
penulis memaparkan dan menjelaskan yang berkaitan dengan Peran Partai Politik Dalam Demokrasi Perwakilan. Penelitian di bidang hukum menggunakan metode penelitian hukum normatif, dan data dianalisis secara kualitatif. Analisis secara kualitatif merupakan analisis dengan mendeskripsikan/menggambarkan, kemudian membandingkan antara data dengan ketentuan-ketentuan peraturan perundang-undangan atau pendapat para ahli hukum. Penarikan kesimpulan dilakukan dengan cara deduktif penyimpulan dari hal-hal yang bersifat umum kepada hal-hal yang bersifat khusus.

\section{Hasil Penelitian dan pembahasan (Peran Partai Politik Dalam Demokrasi Perwakilan).}

Hakikat demokrasi adalah sebuah proses bernegara yang bertumpu pada peran utama rakyat sebagai pemegang tertinggi kedaulatan. Dengan kata lain, pemerintahan demokrasi adalah pemerintahan yang meliputi tiga hal mendasar: pemerintahan dari rakyat (government of the people), pemerintahan oleh rakyat (government by the people) dan pemerintahan untuk rakyat (government for the people). ${ }^{7}$ Demokrasi tidak sekedar wacana ia juga mempunyai parameter sebagai ukuran apakah suatu negara atau pemerintahan bisa dikatakan demokratis atau sebaliknya. Setidaknya tiga aspek dapat dijadikan landasan untuk mengukur sejauh mana demokrasi itu berjalan dalam suatu negara. Ketiga aspek tersebut adalah: ${ }^{8}$

1. Pemilihan umum sebagai proses pembentukan pemerintah. Hingga saat ini pemilihan umum diyakini oleh banyak ahli demokrasi sebagai salah satu instrumen penting dalam proses pergantian pemerintahan;

2. susunan kekuasaan negara, yakni kekuasaan negara dijalankan secara distributif untuk menghindari penumpukan kekuasaan dalam satu tangan atau satu wilayah;

3. kontrol rakyat, yaitu suatu relasi kuasa yang berjalaan secara simetris, memiliki sambungan yang jelas dan adanya mekanisme yang memungkinkan control dan kesimbangan (checks and balance) terhadap kekuasaan yang dijalankan eksekutif dan legislatif.

Semenjak demokrasi menjadi instrumen utama bagi negara modern saat ini yaitu salah satunya adalah negara Indonesia, maka dengan sistem perwakilan ini merupakan metode untuk mengimplementasikan aspirasi dari rakyat dalam sistem demokrasi yang diwakili oleh Dewan Perwakilan Rakyat. Jadi, sebuah pemerintahan suatu negara akan bergantung kepada potensinya untuk mentransformasikan kehendak rakyat sebagai nilai yang tertinggi diatas kehendak Negara itu sendiri.

\footnotetext{
${ }^{7}$ A. Ubaedillah, Pancasila Demokrasi Dan Pencegahan Korupsi, Prenadamedia Group, Jakarta, 2015. HIm 82

${ }^{8} \mathrm{lbid}, \mathrm{HIm} 95$
} 
Perwakilan dalam konteks teori modern merupakan mekanisme hubungan antara penguasa dan rakyat. ${ }^{9}$ Atas dasar prinsip-prinsip normatif yang demikian itu, dalam praktek kehidupan demokrasi, yang awal, lembaga legislatif yang memiliki posisi yang sangat startegis dan sentral yang biasanya tercermin dalam doktrin tentang kedaulatan rakyat serta kedaulatan DPR. Hal ini didasarkan kepada suatu pandangan bahwa hanya DPR saja yang mewakili rakyat dan yang memiliki kompetensi untuk mengungkapkan kehendak rakyat dalam bentuk regulasi negara. ${ }^{10}$

Adanya lembaga parlemen yang dipilih melalui pemilihan umum mengandung arti bahwa demokrasi yang dikembangkan adalah demokrasi tidak langsung. Kedaulatan yang diserahkan oleh rakyat kepada penguasa, orientasinya harus kembali lagi kepada rakyat yaitu kemauan bersama dari anggota-anggota masyarakat yang menyerahkan pelaksanaan kedaulatan itu. Karena sesungguhnya kedaulatan itu berada di tangan rakyat yang diserahkan hanyalah pelaksanaannya saja. Keberadaan lembaga perwakilan rakyat dalam negara demokrasi adalah salah satu pilar yang sangat pokok, karena lembaga ini berfungsi untuk mewakili kepentingan-kepentingan rakyat, menyalurkan aspirasi rakyat serta mengartikulasikan aspirasi tersebut.

Partai memainkan peran penghubung yang sangat startegis antara proses-proses pemerintahan dengan warga negara. Bahkan, Banyak yang berpendapat bahwa partai politiklah yang sebetulnya menentukan demokrasi, seperti dikatakan oleh Schattscheider, "Political Parties Created democracy". Dalam demokrasi kehadiran partai politik adalah suatu keniscayaan dalam rangka memainkan fungsi representasi manakala partai politik masuk ke arena pemilu sebagai peserta hal ini diatur dalam Undang-Undang Nomor 7 Tahun 2017 Tentang Pemilihan Umum Pasal 1 angka 27 yang berbunyi: "Peserta Pemilu adalah partai politik untuk pemilu anggota DPR, anggota DPRD provinsi, anggota DPRD kabupaten/kota, perseorangan untuk pemilu anggota DPD,dan pasangan calon yang diusulkan oleh partai politik atau gabungan partai politik untuk pemilu prisiden dan Wakil Presiden". Dalam pemilu, partai politik boleh dikatakan sebagai aktor tunggal pengisian jabatan dalam lembaga-lembaga negara. Partai politik memainkan peran sebagai pelembagaan ide-ide, pikiran, pandangan dan keyakinan, peran partai politik dapat dikatakan menentukan dinamika kenegaraan partai, politik menjadi agen proses dinamis dalam memperjuangkan nilai dan konstituennya untuk menentukan kebijakan negara. ${ }^{11}$ Dalam negara demokrasi partai politik menyelenggarakan beberapa fungsi:

${ }^{9}$ Leo Austino, Perihal IImu Politik; Sebuah Bahasa Memahami IImu Politik, Graha IImu, Yogyakarta, 2007. HIm 93

${ }^{10}$ P.Anthonius Sitepu, Sistem IImu Politik, Graha IImu, Yogyakarta, 2012. HIm 173

${ }^{11}$ Shidarta, Hukum Penalaran dan Penalaran Hukum, Buku 1 Akar Filosofis, Genta Publishing, Yogyakarta, 2013. HIm. 269 
1. Partai sebagai sarana komunikasi politik, adalah menyalurkan aneka ragam pendapat dan aspirasi masyarakat dan mengaturnya sedemikian rupa sehinga kesimpangsiuran pendapat dalam masyarakat berkurang.

2. Partai sebagai sarana sosialisasi politik, adalah juga main peranan sebagai sarana sosialisasi politik (instrument of political socialization). Dalam ilmu politik sosialisasi politik diartikan sebagai proses melalui mana seseorang memperolehsikap dan orientasi terhadap penomena politik, yang umumnya berlaku dalam masyarakat di mana ia berada.

3. Partai politik sebagai sarana rekruitment politik, juga berfungsi untuk mencari dan mengajak orang yang berbakat untuk turut aktif dalam kegiatan politik sebagai anggota partai (political recruitment).

4. Partai politik sebagai sarana pengatur konflik (conflict management), dalam suasana demokrasi, persaingan dan perbedaan pendapat dalam masyarakat merupakan soal yang wajar. Jika sampai terjadi konflik, partai politik berusaha untuk mengatasi.

Selain fungsi, Partai politik juga memiliki kewenangan istimewa yaitu memberhentikan wakil rakyat sebagaimana terlihat dalam UndangUndang Nomor 2 tahun 2011 tentang partai politik pasal 16 ayat 1 huruf D yang berbunyi "Anggota Partai Politik diberhentikan keanggotaannya dari Partai Politik apabila melanggar AD dan ART" dan Ayat (3) dalam pasal yang sama berbunyi "Dalam hal anggota Partai Politik yang diberhentikan adalah anggota lembaga perwakilan rakyat, pemberhentian dari keanggotaan Partai Politik diikuti dengan pemberhentian dari keanggotaan di lembaga perwakilan rakyat sesuai dengan peraturan perundangundangan" dan Putusan Mahkamah Konstitusi Nomor 39/PUU-XI/2013 tentang pengujian pasal 16 ayat (3) UU Partai Politik, juga memberikan legitimasi bahwa otoritas partai politik dalam memberhentikan anggotanya, Amar putusannya dikecualikan bagi anggota DPR atau DPRD jika: a. partai politik yang mencalonkan anggota tersebut tidak lagi menjadi peserta pemilu atau kepengurusan partai politik tersebut sudah tidak ada lagi, b. anggota DPR atau DPRD tidak diberhentikan atau tidak ditarik oleh partai politik yang mencalonkannya, c.tidak lagi terdapat calon pengganti yang terdaftar dalam daftar calon tetap dari partai yang mencalonkannya; serta kekuasaan istimewa partai politik dalam memberhentikan anggota juga diatur dalam Undang-undang Nomor 2 Tahun 2018 tentang MPR, DPR, DPD dan DPRD Pasal 239 ayat (2) Huruf $d, g$ dan $h$.

Berbagai instrumen hukum yang mengatur tentang pemberhentian dan pergantian antar waktu anggota DPR menunjukkan partai politik memiliki peran yang begitu besar didalamnya. Partai politik dapat mengusulkan pemberhentian anggota DPR, bahkan terhadap alasan tertentu sebagaimana disebutkan dalam Pasal 240 ayat (1) UU MD3, pimpinan partai politik satu-satunya pihak yang dapat mengusulkan pemberhentian tersebut. Terhadap regulasi semacam ini, tentu tidak salah 
apabila partai politik memegang kendali recall anggota-anggotanya yang duduk di parlemen. Oleh karena itu, wajar apabila recall bagi kalangan politisi senayan dianggap sebagai momok, hantu atau ranjau demokrasi. Mengingat kekuasaan yang besar cenderung melahirkan abuse of power pernyataan Lord Acton yang sangat terkenal mengatakan bahwa kekuasaan cenderung disalahgunakan dan kekuasaan yang mutlak pasti disalahgunakan. Namun, mekanisme kontrol itu juga tidak boleh mengesampingkan kedaulatan rakyat, bahkan dapat membelenggu anggota dewan yang menyeruakan aspirasi yang diwakilinya. ${ }^{12}$

Kekuasaan besar yang dimiliki partai politik sehingga dapat merecall anggotanya yang berstatus wakil rakyat. Jika di runut sejarahnya, recall dikenal pada masa pemilu Orde Baru (1971-1997) yang menganut sistem pemilu proporsional murni, sedangkan dalam pemilu 1999 yang juga menganut sistem proporsional murni tidak dikenal recall, dan recall ternyata di hidupkan kembali dalam pemilu 2004 yang menganut sistem pemilu proporsional dengan daftar calon terbuka (bernuansa/semi distrik). ${ }^{13}$

Tabel Recall Kontroversial

\begin{tabular}{|c|c|c|c|}
\hline No & Nama & Partai & Alasan Recall \\
\hline 1 & Azzidin & Partai Demokrat & $\begin{array}{ll}\text { Direcall } & \text { lewat } \\
\text { pemecatan } & \text { Badan } \\
\text { Kehormatan. } & \text { Kasus } \\
\text { katering haij } & \end{array}$ \\
\hline 2 & Marissa Haque & $\begin{array}{l}\text { Partai Demokrasi } \\
\text { Perjuangan Indonesia }\end{array}$ & $\begin{array}{lr}\text { Maju sebagai calon } \\
\text { wakil } & \text { gubernur } \\
\text { dalam } & \text { Pilkada } \\
\text { provinsi } & \text { Banten }\end{array}$ \\
\hline 3 & $\begin{array}{l}\text { Djoko Edhi } \\
\text { Sutjipto } \\
\text { Abdurrahman }\end{array}$ & $\begin{array}{l}\text { Partai } \\
\text { Nasional }\end{array}$ & $\begin{array}{l}\text { Ikut studi banding } \\
\text { RUU perjudian ke } \\
\text { Mesir }\end{array}$ \\
\hline 4 & Zaenal Ma'arif & $\begin{array}{l}\text { Partai } \\
\text { Reformasi }\end{array}$ & $\begin{array}{l}\text { Poligami. Masih } \\
\text { menjadi perdebatan }\end{array}$ \\
\hline
\end{tabular}

Sumber: Hukum Online

Sejarah mencatat Sri Bintang Pamungkas di-recall oleh Partai Persatuan Pembangunan pada 1995. Latar belakangnya Bintang kerap menyampaikan kritik terhadap pemerintah. Puncaknya, Bintang menolak pertanggungjawabannya kepada Soeharto tahun 1993. Tidak terima dengan recall atas dirinya, Bintang menggugat Keputusan Presiden No. 150/M Tahun 1995. Ia mendaftarkan gugatan Tata Usaha Negara 10 Agustus 1995 namun kandas. Hakim menyatakan recall sah. Pada Tahun 2016 kasus Fahri Hamzah wakil ketua DPR di Recall dari Partai Keadilan Sejahtera (PKS) karena tidak patuh dengan kebijakan partai. Buntut

${ }^{12}$ Ni'matul Huda, Imam Nasef, Penataan Demokrasi Dan Pemilu Di Indonesia Pasca Reformasi, Edisi pertama, Kencana, Jakarta, 2017. HIm 176-190

${ }_{13}$ Hukum Online, Mempertanyakan Hegemoni Recall Anggota DPR Di Tangan Partai Politik, 22 Januari 2007, Diakses Tanggal 13 Februari 2020 
panjang kisruh PKS dan Fahri Hamzah begitu panjang sehingga Ketua Majelis Syuro PKS Salim Segaf Aljufri menginstruksikan Fahri mundur dari kursi wakil ketua DPR. Sohibul Imam menyampaikan alasan pemecatan Fahri Hamzah bermula pada tahun 2016 Dewan Pimpinan Tingkat Pusat (DPTP) PKS merilis sejumlah pelanggaran yang dilakukan oleh Fahri Hamzah. Versi DPTP, beberapa pernyataan Fahri Hamzah yang kontroversial, kontraduktif dan tidak sejalan dengan arahan partai saat itu antara lain: ${ }^{14}$

1. Menyebut rada-rada bloon untuk para anggota DPR RI. Pernyataan ini diadukan oleh sebagian anggota DPR RI ke Mahkamah Kehormatan Dewan (MKD) dan di kemudian hari Fahri diputus oleh MKD melakukan pelanggaran ringan;

2. Mengatasnamakan DPR RI telah sepakat untuk membubarkan KPK;

3. Pasang badan untuk 7 (tujuh) proyek DPR RI yang mana hal tersebut bukan merupakan arahan pimpinan partai.

Fahri hamzah tidak terima atas surat keputusan pemecatan dirinya oleh pimpinan partai PKS yang secara otomatis berhenti menjadi wakil rakyat. Kemudian Fahri Hamzah mengajukan keberatan melalui Pengadilan Negeri Jakarta Selatan sesuai dengan Undang-Undang Nomor 2 Tahun 2018 tentang MD3 pasal 241 ayat (1) yang berbunyi: dalam hal anggota partai politik diberhentikan oleh partai politiknya sebagaimana dimaksud dalam pasal 239 ayat (2) huruf d dan yang bersangkutan mengajukan keberatan melalui pengadilan, pemberhentiannya sah setelah adanya putusan pengadilan putusan pengadilan yang telah berkekuatan hukum tetap. Sesuai putusan PN Jaksel dengan nomor perkara 214/Pdf.G/2016/PN JKT.SEL yang memenangkan Fahri sebagai penggugat dan putusan pengadilan tinggi DKI Jakarta dengan nomor perkara 593/PDT/2017/PT.DKI yang menguatkan putusan PN Jaksel. Kemudian Putusan Mahkamah Agung nomor 1876 K/PDT/2018 yang memutuskan menolak kasasi yang dilayangkan DPP PKS. ${ }^{15}$ Nasib Fahri Hamzah sangat beruntung jika dibandingkan dengan nasib Bintang Pamungkas.

\footnotetext{
${ }^{14}$ Berdasarkan alasan-alasan pemecatan Fahri Hamzah membuka suara dengan melontarkan pembelaan-pembelaannya sebagai berikut: (1) pernyataan rada-rada bloon yang dibilang saya telah diputus melanggar kode etik. Saya telah berkirim surat kepada MKD bahwa pernyataan itu hanya metafora ilmiah tentang tugas dan fungsi sistem pendukung. Saya tidak pernah diperiksa MKD datang hanya concern ke beberapa mekanisme yang di MKD belum selesai, (2) Soal bubarkan KPK bagaimana saya bisa mengatasnamakan DPR bersepakat membubarkan KPK, itu kan ada prosedurnya mesti ada amandemen, (3) Dalam proyek DPR saya ditunjuk sebagai ketua tim implementasi reformasi DPR pada saat ditunjuk dan itu disahkan oleh paripurna DPR dalam rapat paripurna juga ada PKS semua setuju tidak ada yang interupsi. Lihat DetikNews, Akhirnya Terungkap, Inilah Alasan Ketua Majelis Syuro PKS Pecat Fahri, Kamis 03 Mei 2018. Diakses tanggal 12 Februari 2020.

${ }^{15}$ Detiknews, 6 Fakta Fahri Hamzah Yang Menang Lawan PKS Rp. 30 M, Kamis, 10 Januari 2019. Diakses Tanggal 13 Februari 2020
} 
Menurut Penulis kekuasaan Partai Politik yang besar mengakibatkan anggotanya yang duduk di kursi DPR tidak bisa berekspresi sesuka hatinya dalam menyuarakan aspirasi rakyat yang diwakilinya mereka harus mematuhi perintah dan arahan partai. Jika tidak patuh, recall sudah membayang-bayangi mereka bisa saja sewaktu-waktu langkah mereka terhenti sebagai wakil rakyat. Sehingga dalam hal ini penulis melihat hubungan antara wakil dan terwakili yang dianut oleh negara Indonesia lebih mirip kepada wakil partisipan. Sebagaimana Abcarian dalam teorinya mengemukakan adanya empat tipe hubungan yang bisa terjadi antar wakil dengan yang diwakili yaitu :16

a. wakil sebagai wakil; dalam tipe ini, wakil bertindak bebas menurut pertimbangannya sendiri tanpa perlu berkonsultasi dengan pihak yang diwakilinya.

b. wakil sebagai utusan; dalam tipe ini wakil bertindak sebagai utusan dari pihak yang diwakili, sesuai dengan mandat yang diberikannya.

c. wakil sebagai politico; dalam tipe ini wakil kadang-kadang bertindak sebagai wali, dan adakalanya bertindak sebagai utusan. Tindakan wakil akan mengikuti keperluan atau masalah yang dihadapi.

d. wakil sebagai partisipan; dalam tipe ini wakil bertindak sesuai dengan program partai atau organisasinya. Wakil akan lepas hubungannya dengan pemilih (pihak yang diwakili) begitu proses pemilihan selesai wakil hanya terikat kepada partai atau organisasi yang mencalonkannya.

Bukan tanpa alasan penulis mengatakan DPR sebagai wakil partisipan melihat konstruksi hukum kita memberikan hak istimewa kepada partai politik untuk merecall anggotanya menjadikan DPR yang dipilih oleh rakyat harus tunduk dan patuh terhadap instruksi partai yang mengusungnya. Kemudian produk hukum yang dibuat oleh DPR yang merupakan wakil rakyat dan pemerintah cenderung ditolak oleh rakyat sebagaimana fenomena yang terjadi saat ini yaitu penolakan terhadap omnibus law masih tetap berlangsung.

Selain itu peristiwa demonstrasi yang terjadi pada tahun 2019 seribuan mahasiswa dan pelajar menolak Undang-Undang KPK dan Rancangan Undang-Undang KUHP di Gedung DPR dan DPRD se Indonesia bahkan mahasiswa melayangkan mosi tidak percaya kepada DPR, tentunya demonstrasi ini berakar dari RUU yang disusun oleh DPR banyak kontroversi dan enggannya DPR membuka diri kepada rakyat terkait RUU yang dirumuskannya terkhusunya Revisi UU KPK yang senyap ${ }^{17}$ dari

${ }^{16}$ Abdy Yuhana, Sistem Ketatanegaraan Indonesia Pasca Perubahan UUD 1945 Sistem Perwakilan Di Indonesia Dan Masa Depan MPR RI, Fokus Media, Bandung, 2013. HIm 56

${ }^{17}$ Bak Operasi senyap tiba-tiba saja DPR mengagendakan rapat paripurna pada kamis (5/9/2019) untuk membahas usulan baleg atas revisi UU KPK, sejak wacana ini menjadi polemik, baleg tidak pernah mempublikasikan rapat pembahasan draf rancangan undang-undang, Kompass.Com, Operasi Senyap Revisi UU KPK, Kamis 5 September 2019. Diakses Tanggal 14 Februari 2020 
pemberitaan sehingga mendapat banyak penolakan dari rakyat yang diwakilinya. Respon DPR melalui ketuanya menyatakan satu-satunya cara untuk mewujudkan tuntutan mahasiswa itu adalah lewat gugatan uji materil UU di Mahkamah Konstitusi kemudian terkait RUU KUHP di tunda pembahasannya padahal UU KPK itu ada karena inisiatif mereka yang katanya wakil rakyat tetapi di saat rakyat menuntut UU itu di cabut tidak ada respon yang memuaskan bagi rakyat. Revisi Undang-Undang Nomor 30 Tahun 2002 tentang Komisi Pemberantasan Tindak Pidana Korupsi menjadi UU KPK dalam sidang paripurna yang digelar, selasa 17 September 2019. Pada saat pengambilan keputusan tingkat pertama, tujuh fraksi; PDIP, Golkar, PPP, Nasdem, PAN, PKB dan Hanura menerima revisi tanpa catatan.

Sementara Dua fraksi yakni Gerindra dan PKS menerima dengan catatan tidak setuju berkaitan pemilihan dewan pengawas yang dipilih tanpa uji kelayakan dan kepatuhan di DPR. Terakhir, Demokrat belum memberikan sikap karena menunggu konsultasi pimpinan fraksi. Kemudian pada saat pembicaraan tingkat dua pengambilan keputusan terhadap RUU tersebut disetujui oleh anggota dewan serentak. Presiden Jokowi mengatakan tidak akan mengeluarkan Peraturan Pemerintah Pengganti Undang-undang (Perppu) UU KPK. Menurutnya, revisi UU KPK adalah inisiatif DPR. ${ }^{18}$ Ketua DPR Bambang Soesatyo menanggapi soal tuntutan mahasiswa soal penghapusan revisi UU KPK yang sudah disahkan menjadi undang-undang. Bamsoet menyebut satu-satunya cara untuk mewujudkan tuntutan mahasiswa itu adalah lewat gugatan uji materil UU di Mahkamah Konstitusi. ${ }^{19}$

Penulis juga menilai tanggapan Presiden Jokowi tidak akan mengeluarkan Perppu terhadap UU KPK karena inisiatif DPR hal ini dinilai kurang tepat. Ada beberapa alasan yang mengakibatkan Presiden mengelurkan Perppu:

1. Mengeluarkan Perppu adalah hak Presiden yang diatur dalam Pasal 22 ayat (1) UUD NRI 1945 berbunyi "dalam hal ihwal kegentingan yang memaksa, Presiden berhak menetapkan peraturan pemerintah sebagai pengganti undang-undang". Kemudian lahir putusan Mahkamah Konstitusi No. 138/PUUVII/2009 yang menetapkan tiga kategori kegentingan yang memaksa. Pertama, adanya keadaan yaitu kebutuhan mendesak untuk menyelesaikan masalah hukum secara cepat berdasarkan undang-undang. Kedua, undang-undang yang dibutuhkan tersebut belum ada sehingga terjadi kekosongan hukum, atau ada undang-undang tetapi tidak memadai. Ketiga, kekosongan hukum tersebut tidak dapat diatasi dengan cara membuat undang-undang melalui prosedur biasa karena akan

${ }^{18}$ Liputan6.com, Jokowi: Revisi UU KPK Insiatif DPR, 23 September 2019, Diakses Tanggal Tanggal 14 Februari 2020

${ }_{19}$ Kompas.com, DPR-Pemerintah Klaim Tuntutan Mahasiswa Dipenuhi, Padahal UU KPK Belum Dicabut, Rabu 25 September 2019, Diakses Tanggal 14 Februari 2020. 
memerlukan waktu yang cukup lama sedangkan keadaan yang mendesak tersebut memerlukan kepastian untuk diselesaikan. Kondisi demonstrasi mahasiswa seluruh Indonesia dengan tuntutan cabut UU KPK masuk kedalam kondisi kegentingan yang memaksa dalam kategori pertama, karena revisi undangundang KPK yang di setujui bersama pemerintah dan DPR mengandung unsur pelemahan KPK sedangkan kondisi negara Indonesia masih darurat permasalahan korupsi yang harus di selesaikan. KPK yang semula adalah lembaga Independen tetapi setelah hadirnya UU baru ini dibentuk Dewan Pengawas yang mana Ketua dan anggota Dewan pengawas di angkat dan ditetapkan oleh Presiden meyebabkan KPK tidak dapat lagi dikatakan sebagai lembaga independen tetapi masuk kedalam rumpun eksekutif.

2. Ketua DPR menyatakan satu-satunya cara untuk mewujudkan tuntutan mahasiswa itu adalah lewat gugatan uji materil UU di Mahkamah Konstitusi. Dengan respon seperti itu DPR tidak akan melakukan legislatif review nya. Dan juga DPR dalam masa transisi upaya legislatif review untuk revisi UU KPK membutuhkan waktu yang lama karena harus masuk kedalam program legislasi nasional sedangkan rakyat mendesak untuk mencabut UU KPK. Upaya yang paling cepat dilakukan adalah mengeluarkan Perppu;

Organisasi dan termasuk juga organisasi partai politik, kadangkadang bertindak dengan lantang dan atas nama kepentingan rakyat tetapi dalam kenyataannya di lapangan justru berjuang untuk kepentingan pengurusnya sendiri. Seperti dikemukakan oleh Robert Michels sebagai suatu hukum besi yang berlaku dalam organisasi bahwa: "Organisasilah yang melahirkan dominasi si terpilih atas para pemilinnya, antara si mandataris dengan si pemberi mandat dan antara si penerima kekuasaan dengan sang pemberi. Siapa saja yang berbicara tentang organisasi, maka sebenarnya ia berbicara tentang oligarki".

Untuk mengatasi berbagai potensi buruk partai politik seperti dikemukakan di atas, diperlukan beberapa mekanisme penunjang. Pertama, mekanisme internal yang menjamin demokratisasi melalui partisipasi anggota partai politik itu sendiri dalam proses pengambilan keputusan. Pengaturan mengenai hal itu sangat penting dirumuskan secara tertulis dalam anggaran dasar (constitution of the party) dan anggaran rumah tangga partai politik yang bersangkutan. Di samping anggaran dasar dan anggaran rumah rangga, sesuai tuntutan perkembangan perlu diperoleh sistem kode etika positif yang dituangkan sebagai Code Of Ethnics yang dijamin tegaknya melalui dewan kehormatan yang efektif.

Kedua, mekanisme keterbukaan partai dimana warga masyarakat di luar partai dapat ikut serta berpartisipasi dalam penentuan kebijakan yang hendak diperjuangkan melalui dan oleh partai politik. Partai politik harus dijadikan dan menjadi sarana perjuangan rakyat dalam turut 
menentukan bekerjanya sistem kenegaraan sesuai aspirasi mereka. Oleh karena itu pengurus hendaklah berfungsi sebagai pelayan aspirasi dan kepentingan bagi konstituennya. Kepengurusan partai politik di masa depan memang sebaiknya diarahkan untuk menjadi pengelola yang profesional yang terpisah dari para calon wakil rakyat. Mungkin ada baiknya untuk dipikirkan bahwa kepengurusan partai politik dibagi kedalam tiga komponen, yaitu: (i) komponen kader wakil rakyat; (ii) komponen kader pejabat eksekutif; dan (iii) komponen pengelolaan profesional. Ketiganya diatur dalam struktur terpisah dan tidak ada yang boleh rangkap jabatan dan pilih jalur. Pola rekrutmen dan promosi diharuskan mengikuti jalur yang sudah ditentukan dalam jalur salah satu dari ketiga jalur tersebut.

Jika seseorang berminat menjadi anggota DPR atau DPRD, ia diberikan kesempatan sejak awal untuk menjadi anggota Dewan Perwakilan Partai atau yang disebut dengan nama lain, yang disediakan tersendiri strukturnya dalam kepengurusan partai. Sementara itu, kader yang berminat duduk dilembaga eksekutif tidak duduk di lembaga dewan perwakilan melainkan duduk dalam dewan kabinet atau yang disebut dengan nama lain. Diluar kedua struktur itu, adalah struktur kepengurusan biasa yang dijabat oleh para profesional yang digaji oleh partai dan tidak dimaksudkan untuk direkrut menjadi wakil rakyat ataupun dipromosikan menduduki jabatan di lingkungan pemerintahan. Ketiga kelompok pengurus tersebut hendaknya jangan dicampur aduk atau terlalu mudah berpindah-pindah posisi dan jalur. ${ }^{20}$

Mekanisme recall menghadapi dilema dalam sistem ketatanegaraan, mengingat UUD NRI 1945 telah memperkuat asas kedaulatan rakyat. Oleh karena itu, muncul wacana untuk melibatkan rakyat dalam mekanisme recall. Alasan utama pentingnya rakyat dilibatkan dalam mekanisme recall dan demokrasi pasca reformasi yang diikuti dengan amandemen konstitusi, kedudukan kedaulatan rakyat lebih diperkuat lagi. Pasal 1 ayat (2) UUD NRI 1945 menegaskan bahwa "kedaulatan berada di tangan rakyat dan di laksanakan berdasarkan Undang-Undang Dasar." Secara yuridis konstitusional, sangat jelas disebutkan bahwa negara Indonesia menganut asas kedaulatan rakyat. Berdasarkan asas kedaulatan rakyat, pemilik kekuasaan tertinggi yang sesungguhnya adalah rakyat, walaupun dalam pelaksanaannya harus sesuai dengan prosedur konstitusional sebagaimana ditetapkan dalam hukum dan konstitusi (constitusional democracy). Sistem politik demokratis telah menjadi keniscayaan dalam mengakomodasi hak-hak asasi manusia termasuk salah satunya hak politik. Terkait hak politik Harold J Laski menegaskan bahwa sistem demokrasi memberikan saluran kepada warga negara untuk berhubungan langsung dengan sumber

${ }^{20}$ Jimly Asshiddiqie, Pengantar IImu Hukum Tata Negara, PT Raja Grafindo Persada, Jakarta, Cet 8 2016. HIm 410-411 
kewenangan, sehingga warga negara memiliki hak untuk kekuasaan politik. $^{21}$

Dalam rangka mengimplementasikan asas kedaulatan rakyat dan demokrasi di atas, sudah selayaknya rakyat dilibatkan dalam mekanisme recall, Logika sederhananya adalah apabila rakyat sebagai pemegang kedaulatan berhak memilih siapa wakilnya, maka semestinya pemilih juga punya hak untuk memberhentikan atau setidak-tidaknya mengusulkan pemberhentian seorang anggota DPR. Bahkan lebih jauh Jimly Asshiddiqie berpendapat, bahwa dalam sistem yang sejati sistem party recall sudah seharusnya ditiadakan dan diganti dengan sistem constituent recall yaitu apabila tuntutan pemberhentian terhadap anggota itu datang dari warga masyarakat daerah pemilihan dari mana anggota DPR yang bersangkutan berasal, atau paling tidak minimal rakyat dilibatkan.

Sistem Perwakilan Yang Dianut Indonesia

Demokrasi perwakilan adalah bentuk pemerintahan yang di dalamnya warga masyarakat bisa menjalankan hak yang sama dalam menjalankan pengambilan keputusan politik, tetapi tidak dalam kapasitas personal tetapi melalui perwakilan yang ditunjuk dan bertanggung jawab terhadapnya. Dua elemen yang paling esensial dalam demokrasi perwakilan adalah pemisahannya antara pemerintah dan warga masyarakat, dan secara periodik diselenggarakan pemilihan umum sebagai wahana warga masyarakat mengontrol pemerintah. Jadi mempercayakan sepenuhnya pengambilan keputusan ditingkat parlemen dan pemerintahan melalui sistem pemilihan umum. ${ }^{22}$ Pada pokoknya kekuasaan untuk atau membuat aturan dalam kehidupan bernegara dikonstruksikan berasal dari rakyat yang berdaulat yang dilembagakan dalam organisasi Negara di lembaga Legislatif sebagai Lembaga Perwakilan Rakyat. $^{23}$

Ketika pertama kali didirikan pada tahun 1945, struktur Parlemen Negara kita di idealkan berkamar tunggal (Unikameral) tetapi dengan variasi yang dikaitkan dengan dengan teori kedaulatan Rakyat yang dibayangkan dapat diorganisasikan secara total kedalam suatu organ bernama Majelis Permusyawaratan Rakyat. Majelis ini yang dianggap sebagai penjelmaan seluruh rakyat dan pelaku sepenuhnya kedaulatan Rakyat itu, sehingga diidealkan menjadi lembaga yang tertinggi dalam bangunan organisasi Negara. ${ }^{24}$

Periode akhir pemerintahan orde baru membawa perubahan yang cukup besar dalam kehidupan ketatanegaraan Indonesia. Dalam perspektif perubahan ketatanegaraan Indonesia pasca perubahan

${ }^{21}$ Ni'matul Huda, Imam Nasef, Penataan Demokrasi Dan Pemilu Di Indonesia Pasca Refor..O.p.Cit, HIm192

${ }^{22}$ Suyatno, Menjelajahi Demokrasi, Humaniora, Bandung, 2008. HIm 67

${ }^{23}$ Jimly Asshidiqie, Perihal Undang-Undang, PT Raja Grafindo Persada, Jakarta, 2010. HIm 147

${ }^{24}$ Jimly Asshiddiqie, Hukum Tata Negara Dan Pilar-Pilar Negara Demokrasi, Sinar Grafika, Jakarta, 2015. HIm 
Undang-undang Dasar 1945, seperti halnya penerjemahan kedaulatan Rakyat, yang semula menurut UUD 1945 (sebelum perubahan), dilaksanakan sepenuhnya oleh Majelis Permusyawaratan Rakyat (MPR), diubah menjadi kedaulatan berada ditangan Rakyat dan dilaksanakan menurut Undang-undang Dasar. Hal ini tertuang dalam pasal 1 ayat (2) UUD 1945.

Demikian pula dalam segi kelembagaan, juga terjadi perubahan yang mendasar yakni persamaan kedudukan lembaga Negara secara horizontal dan dihapuskannya kelembagaan Negara berdasarkan prinsip hubungan vertikal, yakni tingkatan Lembaga negara dari posisi Lembaga tertinggi dan Lembaga tinggi negara. ${ }^{25}$ Lembaga Negara Indonesia adalah Lembaga-lembaga negara yang dibentuk berdasarkan Undang-undang Dasar, Undang-undang, atau oleh peraturan yang lebih rendah. ${ }^{26}$

Reformasi pada lembaga legislatif diantaranya adalah perubahan sistem Unicameral (yang telah menempatkan kedudukan MPR sebagai lembaga tertinggi atau supremasi MPR) menuju sistem bicameral dengan mengadakan perubahan komposisi MPR dimana keanggotaan MPR terdiri dari anggota-anggota DPR dan DPD yang kesemuanya dipilih melalui pemilihan umum. ${ }^{27}$ Muncul wacana perlunya lembaga perwakilan yang mewakili wilayah di tingkat pusat untuk melengkapi lembaga perwakilan yang mewakili aspirasi dan paham politik (DPR) dalam struktur ketatanegaraan kita. Wacana ini muncul sebagai respon atas pengalaman pada pemerintahan sebelumnya dimana hubungan pusat dan daerah tidak harmonis dan pemerintahan dijalankan dengan sentralistik. Keragaman dan ciri khas daerah tidak mendapat ruang memadai untuk hidup dan berkembang karena pada era tersebut yang diutamakan dan dipentingkan adalah persatuan dan kesatuan. Berikut ini adalah hasil dari perdebatan dan lobi dari berbagai fraksi, yaitu :

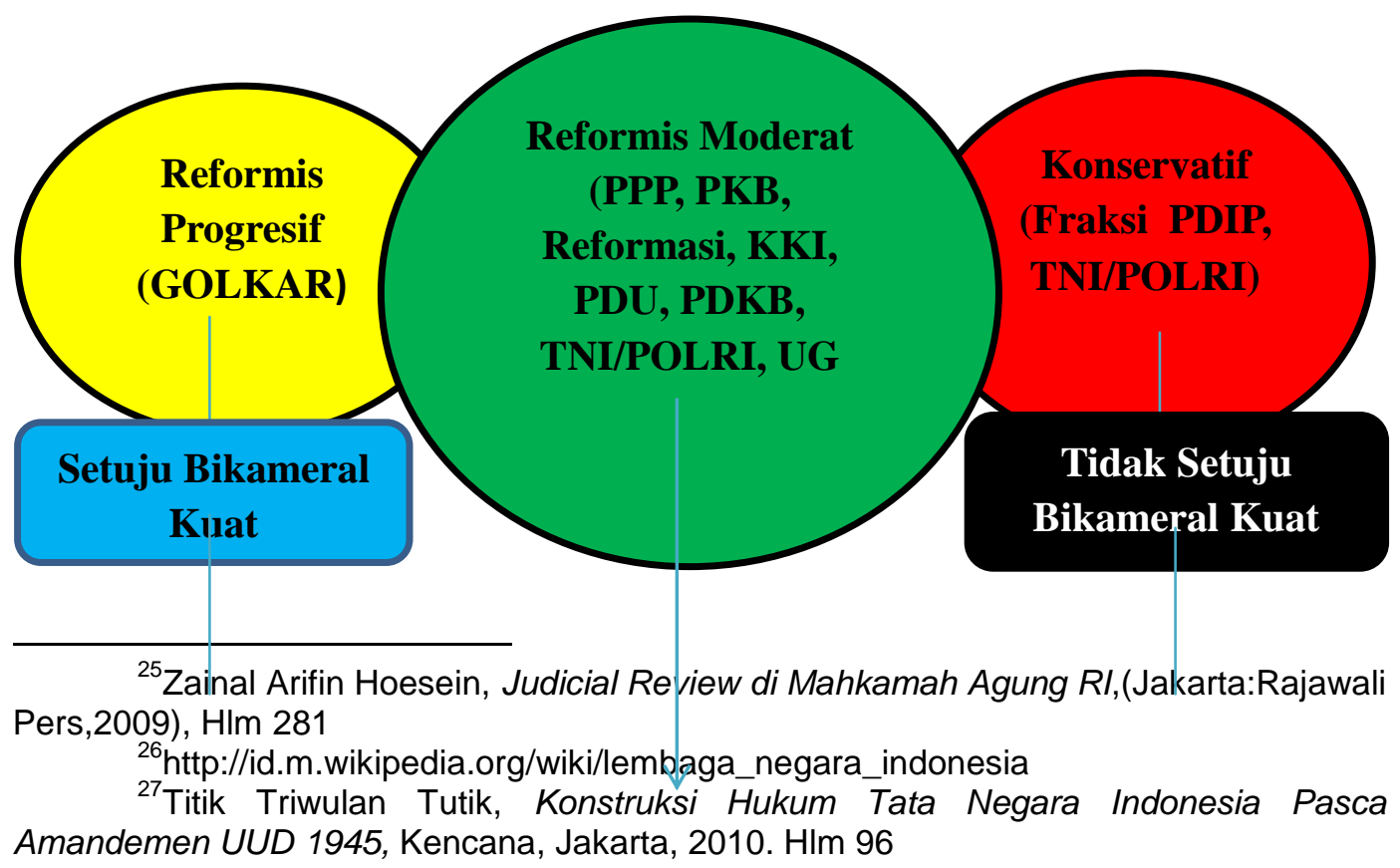




\section{Hasil akhir: DPD dengan kewenangan legislasi terbatas}

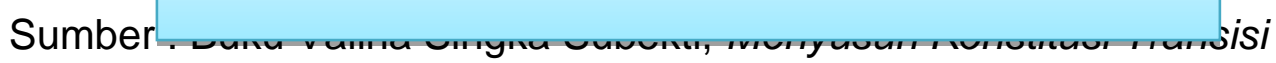

Ketentuan UUD NRI 1945 mengatur keberadaan DPD dalam struktur ketatanegaraan Indonesia itu antara lain dimaksudkan untuk:

1) Memperkuat ikatan daerah-daerah dalam wadah Negara Kesatuan Republik Indonesia dan memperteguh kesatuan kebangsaan seluruh daerah;

2) Meningkatkan agregasi dan akomodasi aspirasi dan kepentingan daerah-daerah dalam perumusan kebijakan nasional berkaitan dengan negara dan daerah;

3) Mendorong percepatan demokrasi, pembangunan dan kemajuan daerah secara serasi dan seimbang.

Dengan demikian, keberadaan daerah sebagaimana dimaksud dalam Pasal 18 ayat (1) dan otonomi daerah sebagaimana dimaksud dalam Pasal 18 ayat (5) berjalan sesuai dengan keberagaman daerah dalam rangka kemajuan bangsa dan negara. DPD memiliki fungsi yang terbatas di bidang legislasi, anggaran, pengawasan dan pertimbangan. Fungsi DPD berkaitan erat dengan sistem saling mengawasi dan saling mengimbangi dalam sistem ketatanegaraan Indonesia, yaitu : ${ }^{28}$

(1) dapat mengajukan kepada Dewan Perwakilan Rakyat rancangan undang-undang yang berkaitan dengan otonomi daerah, hubungan pusat dan daerah, pembentukan dan pemekaran serta penggabungan daerah, pengelolaan sumber daya alam dan sumber daya ekonomi lainnya, serta yang berkaitan dengan perimbangan keuangan pusat dan daerah;

(2) ikut membahas rancangan undang-undang yang berkaitan dengan otonomi daerah, hubungan pusat dan daerah, pembentukan dan pemekaran serta penggabungan daerah, pengelolaan sumber daya alam dan sumber daya ekonomi lainnya, serta yang berkaitan dengan perimbangan keuangan pusat dan daerah;

(3) dapat melakukan pengawasan atas pelaksanaan undangundang mengenai otonomi daerah, pembentukan dan pemekaran serta penggabungan daerah, pengelolaan sumber daya alam dan sumber daya ekonomi lainnya, serta yang berkaitan dengan perimbangan keuangan pusat dan daerah.

Dengan hadirnya DPD membawa perubahan dalam sistem perwakilan Indonesia. Keterwakilan anggota DPR dengan anggota DPD yang sama-sama mewakili daerah di badan perwakilan tingkat nasional

${ }^{28}$ A.M Fatwa, Potret Konstitusi Pasca Amandemen UUD 1945, Kompas, Jakarta, 2009. HIm 127 
mengandung beberapa perbedaan prinsip, antara lain walaupun anggota DPR dipilih berdasarkan daerah-daerah pemilihan dari seluruh Indonesia, namun anggota-anggota DPR itu dicalonkan dan berasal dari partai politik peserta pemilu sehingga DPR itu dikenal sebagai perwakilan politik sehingga mewakili dua kepentingan sekaligus, yaitu kepentingan partai politik dan kepentingan rakyat daerah yang diwakilinya. Pada sisi lain anggota DPD adalah berasal dari calon perseorangan dari daerah yang bersangkutan dan dipilih secara langsung oleh rakyat di daerah tersebut. Pada posisi yang demikian, para anggota DPD hanya akan secara murni menyuarakan kepentingan-kepentingan daerahnya, yaitu seluruh aspek yang terkait dengan daerah yang diwakilinya. ${ }^{29}$ Penulis menilai kewenangan DPD begitu lemah untuk sekelas lembaga negara yang kewenangannya diberikan UUD NRI 1945 apalagi recruitmen anggota DPD melalui proses demokratis. Lebih sulit syarat untuk menjadi anggota DPD daripada anggota DPR. Mengingat anggota DPD pencalonan dilakukan secara perseorangan harus mengumpulkan fotocopy e-ktp ${ }^{30}$ dan juga jumlah kursi yang diperebutkan relatif sedikit.

Terkait sistem perwakilan legislatif yang dianut di Indonesia, menurut Jimly Asshiddiqie, Indonesia saat ini dianggap sebagai salah satu model negara yang menerapkan model tiga kamar. Dikatakan tiga kamar karena masingmasing lembaga yaitu Majelis Permusyawaratan Rakyat, Dewan Perwakilan Rakyat dan Dewan Perwakilan Rakyat Daerah berfungsi sebagai lembaga permanen dan memiliki kewenangan yang berbedabeda. Walaupun pemikiran ini tidak cukup banyak mendapat dukungan dari pihak lain. Bahkan banyak juga yang menyatakan bahwa model Indonesia bukanlah model tiga kamar karena tidak menunjukkan adanya tiga kamar yang yang memiliki kekuatan yang sama. Senada dengan hal tersebut, menurut Bagir Manan, rumusan Undang-Undang Dasar Negara Republik Indonesia Tahun 1945 sama sekali tidak mencerminkan sistem

29 Teuku syaiful Bahri Johan, Hukum Tata Negara Dan Hukum Administrasi Negara Dalam Tataran Reformasi Ketatanegaraan Indonesia, Deepublish, Yogyakarta, 2018. HIm 330

${ }^{30}$ Pasal 183 Ayat (1) Undang-undang Nomor 7 Tahun 2017 Tentang Pemilihan Umum yaitu : Provinsi dengan jumlah penduduk yang termuat di dalam daftar Pemilih tetap sampai dengan 1.000 .000 (satu juta) orang wajib mendapatkan dukungan paling sedikit 1.000 (seribu) Pemilih; provinsi dengan jumlah penduduk yang termuat di dalam daftar Pemilih tetap lebih dari 1.000.000 (satu juta) sampai dengan 5.000.000 (lima juta) orang wajib mendapatkan dukungan paling sedikit 2.000 (dua ribu) Pemilih; provinsi dengan jumlah penduduk yang termuat di dalam daftar Pemilih tetap lebih dari 5.000.000 (lima juta) sampai dengan 10.000.000 (sepuluh juta) orang wajib mendapatkan dukungan paling sedikit 3.000 (tiga ribu) Pemilih; provinsi dengan jumlah penduduk yang termuat di dalam daftar Pemilih tetap lebih dari 10.000.000 (sepuluh juta) sampai dengan 15.000 .000 (lima belas juta) orang wajib mendapatkan dukungan paling sedikit 4.000 (empat ribu) Pemilih; dan provinsi dengan jumlah penduduk yang termuat di dalam daftar Pemilih tetap lebih dari 15.000 .000 (lima belas juta) orang harus mendapatkan dukungan paling sedikit 5.000 (lima ribu) Pemilih. 
perwakilan dua kamar. Karena MPR mempunyai anggota dan lingkungan wewenang sendiri-sendiri, demikian pula DPR dan DPD. Sehingga lembaga perwakilan Indonesia menjadi tiga badan yang mandiri yaitu MPR, DPR, dan DPD.

Terkait dengan Indonesia apakah menerapkan model bikameral atau trikameral, dapat dilihat dari dua hal : yang pertama, Indonesia dapat saja dikatakan menerapkan model trikameral karena adanya tiga lembaga yang melaksanakan fungsi dan struktur yang berbeda, yaitu MPR, DPR dan DPD. Yang kedua, Indonesia dikatakan menerapkan model bikameral, karena pada kenyataannya memang hanya ada dua kamar yang aktif dalam melaksanakan tugas-tugas legislatif seperti penyusunan undang-undang, yaitu DPR dan DPD. Akan tetapi, walaupun disebut model bikameral yaitu model bikameral yang tidak sempurna karena ada ketimpangan antara kewenangan DPR dan DPD. Dengan demikian lebih tepatnya sistem perwakilan yang dianut Indonesia merupakan sistem yang khas Indonesia karena dibentuk sebagai perwujudan kebutuhan, kepentingan serta tantangan bangsa dan negara Indonesia

\section{Kesimpulan}

Konstruksi hukum memberikan peran besar kepada partai politik untuk merecall anggotanya yang duduk di kursi DPR menandakan bahwa negara Indonesia menganut perwakilan partisipan yaitu wakil bertindak sesuai dengan program partai atau organisasinya. Berbagai pendapat dikemukan oleh Para ahli mengenai sistem perwakilan yang dianut oleh Indonesia seperti Jimly Asshiddiqie dan Bagir Manan mengatakan Indonesia mengarah kepada sistem perwakilan trikameral yaitu MPR, DPR dan DPD yang memiliki struktur dan kewenangan tersendiri. Meskipun begitu ada juga pendapat yang mengatakan bahwa Indonesia menganut sistem bikameral lemah yaitu DPR dengan fungsi legislasinya dan DPD dengan fungsi legislasi terbatas. Dengan begitu lebih tepatnya sistem perwakilan yang dianut Indonesia merupakan sistem yang khas Indonesia.

\section{DAFTAR PUSTAKA}

\section{A. Buku-Buku}

Abdy Yuhana, Sistem Ketatanegaraan Indonesia Pasca Perubahan UUD 1945 Sistem Perwakilan Di Indonesia Dan Masa Depan MPR RI, Fokus Media, Bandung, 2013

A.M Fatwa, Potret Konstitusi Pasca Amandemen UUD 1945, Kompas, Jakarta, 2009 
A. Ubaedillah, Pancasila Demokrasi Dan Pencegahan Korupsi, Prenadamedia Group, Jakarta, 2015

Hartati, Menatap Masa Depan Dewan Perwakilan Daerah, CV Trisar Mitra Utama, Jambi, 2018

Jimly Asshiddiqie, Hukum Tata Negara Dan Pilar-Pilar Negara Demokrasi, Sinar Grafika, Jakarta, 2015. $\begin{array}{ll}\text { Grafika, } & \text { Konstitusi \& Konstitusionalisme Indonesia, Sinar } \\ \text { Jakarta, } 2011\end{array}$
, Pengantar Ilmu Hukum Tata Negara, Cet 8, PT Raja Grafindo Persada, Jakarta, 2016 Jakarta, 2010

Leo Austino, Perihal IImu Politik; Sebuah Bahasa Memahami IImu Politik, Graha IImu, Yogyakarta, 2007

Marojahan JS Panjaitan, Politik, Hak Asasi Manusia Dan Demokrasi Dalam Bingkai Negara Kesejahteraan Dan Kebahagiaan Menurut UUD 1945, Rineka Cipta, Bandung, 2018

Ni'matul Huda, Imam Nasef, Penataan Demokrasi Dan Pemilu Di Indonesia Pasca Reformasi, Edisi pertama, Kencana, Jakarta, 2017

P.Anthonius Sitepu, Sistem IImu Politik, Graha IImu, Yogyakarta, 2012

Salim HS dan Erlies Septiana Nurbani, Penerapan Teori Hukum Pada Penelitian Tesis dan Desertasi, PT Raja Grafindo, Jakarta 2013

Shidarta, Hukum Penalaran dan Penalaran Hukum, Buku 1 Akar Filosofis, Genta Publishing, Yogyakarta, 2013

Suratman, Metode Penelitian Hukum, Alfabeta, Bandung, 2014

Suyatno, Menjelajahi Demokrasi, Humaniora, Bandung, 2008

Teuku syaiful Bahri Johan, Hukum Tata Negara Dan Hukum Administrasi Negara Dalam Tataran Reformasi Ketatanegaraan Indonesia, Deepublish, $\quad$ Yogyakarta, 2018

Titik Triwulan Tutik, Konstruksi Hukum Tata Negara Indonesia Pasca Amandemen UUD 1945, Kencana, Jakarta, 2010 , Pengantar IImu Hukum, Prestasi Pustaka, Jakarta, 
Valina Singka Subekti, Menyusun Konstitusi Transisi, PT Raja Grafindo Persada, Jakarta, 2008

Winarno Surahcmad, Pengantar Penelitian IImiah, (Dasar, Metode, Teknik), Tarsito,Bandung, 1990

Zainal Arifin Hoesein, Judicial Review di Mahkamah Agung RI, Rajawali Pers, Jakarta, 2009

\section{B. Peraturan Perundang-Undangan}

Undang-Undang Dasar Negara Republik Indonesia Tahun 1945

Undang-Undang Nomor 2 Tahun 2018 Tentang MPR, DPR, DPD Dan DPRD

Undang-Undang Nomor 7 Tahun 2017 Tentang Pemilihan Umum Undang-Undang Nomor 2 tahun 2011 Tentang Partai Politik Putusan Mahkamah Konstitusi Nomor 39/PUU-XI/2013 Tentang Pengujian Pasal 16 Ayat (3) Undang-Undang Partai Politik Tentang Pemberhentian Anggota DPR atau DPRD

Putusan Mahkamah Konstitusi Nomor 138/PUU-VII/2009 Tentang Pengujian Peraturan Pemerintah Pengganti UndangUndang Nomor 4 Tahun 2009 Tentang Hal Ihwal Kegentingan Yang Memaksa

\section{Internet}

DetikNews, Akhirnya Terungkap, Inilah Alasan Ketua Majelis Syuro PKS Pecat Fahri, Kamis 03 Mei 2018. Diakses tanggal 12 Februari 2020

Detiknews, 6 Fakta Fahri Hamzah Yang Menang Lawan PKS Rp. 30 M, Kamis, 10 Januari 2019. Diakses Tanggal 13 Februari 2020

http://id.m.wikipedia.org/wiki/lembaga_negara_indonesia

Hukum Online, Mempertanyakan Hegemoni Recall Anggota DPR Di Tangan Partai Politik, 22 Januari 2007, Diakses Tanggal 13 Februari 2020

Kompas.Com, Operasi Senyap Revisi UU KPK, Kamis 5 September 2019. Diakses Tanggal 14 Februari 2020

Kompas.com, DPR-Pemerintah Klaim Tuntutan Mahasiswa Dipenuhi, Padahal UU KPK Belum Dicabut, Rabu 25 September 2019, Diakses Tanggal $14 \quad$ Februari 2020 
Liputan6.com, Jokowi: Revisi UU KPK Insiatif DPR, 23 September 2019, Diakses Tanggal Tanggal 14 Februari 2020 